ARTICLES

Copyright (c) 2013

SBPjor / Associação

Brasileira de

Pesquisadores em

Jornalismo

\author{
SCIENTIFIC \\ DISSEMINATION \\ DISCOURSE
}

\title{
a study of specialized magazines \\ disseminating science to lay audiences
}

\author{
ELIZABETH MORAES GONÇALVES \\ Universidade Metodista de São Paulo
}

\begin{abstract}
Scientific Dissemination enunciations in the media are form of public discourse that integrates social, cultural, ideological and political aspects related to their spatial and temporal context. With theoretical support of Discourse Analysis the article presents distinct modes of disseminating science to the lay audience found in three magazines disseminating scientific knowledge: the Scientific American Brazil, Pesquisa Fapesp and Superinteressante. The editorial commitment of each one of these magazines to its readers is the basis of the discursive construction. The Scientific American Brazil draws on many sources for its explanations using a technical approach and close proximity to the patterns of science. The Pesquisa FAPESP magazine addresses the themes in their Brazilian context, uses Brazilian scientists as sources and adopts the journalistic reporting genre with exts by specislized journalists. Superinteressante magazine has a has a more distant commitment to science with exts free from using, instead, catch phrases, slang and types of comparison appropriate the language of its audience.
\end{abstract}

Keywords: Communication. Scientific dissemination. Speech.

\section{OS DISCURSOS DA DIVULGAÇÃO CIENTÍFICA: um estudo de revistas especializadas em divulgar ciência para o público leigo}

RESUMO - Os discursos de Divulgação Científica na mídia constituem uma forma de discurso público que integra os aspectos sociais, culturais, ideológicos, políticos e econômicos relacionados com o contexto de tempo e espaço. Com subsídio teórico da Análise de Discurso, o texto apresenta modos distintos de divulgar ciência para o público leigo em três revistas de Divulgação Científica: Scientific American Brasil, Pesquisa Fapesp e Superinteressante. O compromisso editorial de cada uma das revistas com seus leitores está na base da construção discursiva. A Scientific American Brasil busca nas explicações de muitas fontes e abordagem técnica a proximidade com a ciência. A Revista Pesquisa FAPESP recorta a temática para o contexto nacional e busca as explicações também de cientistas brasileiros e explora o gênero reportagem jornalística, por meio do qual o jornalista especializado atua. A revista Superinteressante tem um contrato mais distante da cientificidade, livre dos jargões científicos, usando gírias e comparações próprias do linguajar do seu público.

Palavras-chave: Comunicação. Divulgação Científica. Discurso. 


\section{EL DISCURSO DE DIVULGACIÓN CIENTÍFICA: un estudio de revistas especializadas en divulgar la ciencia al público lego}

RESUMEN - Los discursos de divulgación científica en los medios de comunicación son una forma de discurso público que integra aspectos sociales, culturales, ideológicos y políticos relacionados con el contexto de tiempo y espacio. Con apoyo teórico del Análisis del discurso, el texto presenta modos distintos de presentar la ciencia al público lego en tres revistas de divulgación científica: Scientific American Brasil, Pesquisa FAPESP (Fundación de Apoyo a la Investigación del Estado de São Paulo) y Superinteressante. El compromiso editorial de cada una de las revistas con sus lectores es la base de la construcción discursiva. La Scientific American Brasil, busca en las explicaciones de muchas fuentes y el enfoque técnico, la proximidad con la ciencia. La revista Pesquisa FAPESP, que selecciona la temática del contexto brasileño con explicaciones de científicos brasileños, explora el género del reportaje periodístico, por medio del cual actúa el periodista especializado. La revista Superinteressante tiene un contrato más distante de la cientificidad y, libre de la jerga científica, utiliza un lenguaje informal propio de su público.

Palabras clave: Comunicación. Divulgación científica. Discurso.

\section{SCIENCE FOR THE LAYMAN}

There is no precise date for when the dissemination of scientific knowledge began in Brazil and there is considerable divergence among researchers due to variation in their conceptions of it. While some consider Dissemination of Science to be intrinsic to its very production and as always having accompied its development (MACEDO, 2002; MASSARANI; MOREIRA, 2004), others declare that the activity first emerged in the $17^{\text {th }}$ century when modern science felt that it was necessary to include knowledge of how the universe functions in people's education (REIS, 2001; CALVO HERNANDO, 2006).

The first records of any attempt to disseminate data resulting from scientific investigation took the firm of books, conferences and demonstrations of experiments, all offered to a very limited audience. According to Macedo (2002), distribution to a wider audience actually began in the 16th century with the publication of the first scientific periodicals. However, their outreach is questioned by Reis (2001) who illustrates his point declaring that:

"a representative of that effort to spread scientific knowledge
would supposedly be Bernier le Bovier de Fontenelle's book entitled
"Entretiens sur la pluralite des mondes" [Conversations on the
plurality of worlds] published in 1686. [...] Can we really consider
Fontenelle to have been popularizing science when he wrote strictly
for the aristocracy, which was the only class interested in that kind 
of knowledge, and when he expressed his own conviction that scientific knowledge should be a privilege of the elite? (REIS, 2001).

The creation of a publishing house in Brazil took place in 1810 with the advent of the Portuguese Court and the setting up of the Imprensa Régia. That made it possible to print texts and manuals to serve the purpose of scientific education, "as the first periodicals with science-related articles and news items began to circulate" (BRASILIANA, 2009).

Today, the media's dissemination of information on the progress of science and technology has given the lay audience opportunities to build its knowledge in an area that has traditionally been renowned for its great complexity and for being almost impossible to gain access to. Although the activity of disseminating scientific knowledge is not something new, the greater part of the growth in the media associated to this segment has taken place in the last few decades, whether in the contents of newspapers and magazines or as part of television programs and, more recently, in websites maintained by universities and research institutions.

The dissemination of science is highly demanded by today's society due to its important role in the construction of citizenship. Studies targeting this segment in a discursive perspective show us that it is not a neutral activity, nor is it purely a form of journalism insofar as there are magazines with very different editorial profiles, offering distinctly different approaches to the themes they address and establishing different forms of relationship with their reading audience. Thus it could be construed that there are in fact various different discourses of Scientific Knowledge dissemination or different genres or sub-genres within the same single media segment.

In that light we selected three Scientific Dissemination magazines for the purposes of this study with distinctly different profiles and target audiences. As the space offered by an article is insufficient for the presentation of a detailed analysis of all the selected material we have opted to present a synthesis of the results obtained by a research project constructed over a period of two years.

As regards the selected magazines, the Scientific American Brasil is quite sophisticated insofar as it addresses an audience that is specifically interested in science and the evolution of technology. The Pesquisa FAPEP (FAPEP Research) magazine, on the other hand, because it is attached to a São Paulo state Institution dedicated to stimulating scientific research and free from the encumbrance of commercial relations 
associated to the media, addresses both science and its readership in a highly technical vein. The third magazine, Superinteressante (Superinteresting) has a totally commercial profile designed to reach out to a more youthful audience which is more interested in all that is fantastic or even entertaining in the Scientific dissemination medium. Thus the discussion of the relations between science, specialized media and society takes on greater relevance because it can be understood that this last kind of publication needs to perform an indispensable social function in understanding, explaining and interacting with its readers to ensure that people become aware of their citizenship and their participation in the destiny of the nation and the world.

Studies of argumentation and/or persuasion in comparative analyses in the field of journalism are very frequent and they generally reveal the subjectivity that permeates the I-you relations established in the media texts. In the case of Scientific Dissemination texts, however, there exists a stereotyped vision of an essential objectivity that must mark the quest for truth that is typical of science and so the studies have generally been limited to identifying the marks of such objectivity. We, however, understand Scientific Dissemination to be part of the media machine, whether through the commercial or institutional ties of the publication or in the relations that unite the science disseminating entity to the audience that it targets.

While non scientist members of the audience targeted by media publications disseminating scientific knowledge can be referred to generically as "laymen", distinctly different levels of scientific knowledge and different ways of relating to it can be found among them. Thus it would never be possible to address in the same way the sophisticated reading audience of the Scientific American that is familiar with a more technical vocabulary and takes a professional interest in the information stemming from the evolution of science and technology and the audience of the Superinteressante magazine, avid for novelty and the unusual; the more fantastical facets of scientific information. Similarly the Pesquisa FAPESP magazine's bond with a research institution removes it somewhat from the commercial sphere and imposes a different form of Scientific Dissemination production on it.

Furthermore, recent theoretical reflections on the discourse, especially those made by Maingueneau and Charaudeau, placing emphasis on the ways of saying made evident as much by the act of enunciation as by what is enunciated, enable us to identify the ethos of the science disseminator in the light of the image formed of the target 
audience and consequently of the tacit contract established between the publication and its audience. Knowledge of the best form of relationship with the audience in question leads to publications with distinct editorial profiles designed to address their respective specificities. The preference of a given group of readers for a title, according to Véron (2004) depends more on the social representations of the readers themselves than on the discursive properties of the title. The readers' cultural baggage, for example may influence their choice to consume one title rather than another.

On the other hand, speaking of the commercial context, Ferreira (2003, p. 269) states that, "the type of journalistic discourse obeys a tradition insofar as it is a branch of cultural production, subject, after a certain time, to the laws of competition. The reading contract is actually forged by the laws of the market".

The three magazines object of this study relate to the market in very different ways. While the Superinteressante, published by the Abril group, has the appearance typical of a highly commercial product, given that $50 \%$ of its pages are given over to advertising, the Scientific American Brasil has, on average, just ten advertisements in each issue (advertisements for cultural or technological services or products) and the Pesquisa FAPESP magazine only has advertisements on the inside covers and they take the form of announcements of the research foundation itself.

\section{ABOUT THE MAGAZINES}

The Scientific American Brasil magazine is produced by Duetto Editorial, a publishing house founded in April, 2001 by the fusion of two important Brazilian publishers: a Ediouro Publicações, based in Rio de Janeiro, and Editora Segmento, with headquarters in São Paulo.

The very first number of the original Scientific American was published on April 28, 1845 and ever since then it has occupied a considerable space in the scientific publications market fulfilling its intended role of Scientific Dissemination. According to information on its site, in 1845, then editor Rufus Porter underscored his firm belief in the magazines proposal in these words: "(the publication) will retain its excellence and its value long after others have been forgotten» (SCIENTIFIC, 2009).

During this long period of its existence, the magazine has publicized scientific discoveries and technological inventions of the 
greatest importance for human progress such as the telephone, the incandescent lamp, X-rays, Lumière's invention of the cinematograph, television, interplanetary journeys, the discovery of the neutron and the splitting of the atom, the development of the transistor, the optic fiber and the discovery of DNA.

Currently, the Scientific American Brasil belongs to a pool of international publications published in 16 languages and in 20 countries that include: the United States, Canada, Germany, France, Italy, Spain, Poland and Japan. Brazil is the twentieth country to publish an edition of the magazine (SCIENTIFIC, 2009).

The Pesquisa FAPESP monthly magazine created in 1999 and produced by the State of São Paulo's Research Support Foundation is sold on newsstands and by subscription (commercial circulation began in 2002) and it accepts advertising. According to its introduction on the site, the magazine, "it is the result of the evolution of what was originally an informative newssheet Nóticias FAPESP (FAPESP News). The latter was launched in August 1955 and was originally distributed free of charge to São Paulo researchers, public administrators of the Brazilian national policy on science and technology and to journalists. Four years later it became a magazine (REVISTA PESQUISA FAPESP, 2009).

Today each issue of the Pesquisa FAPESP has a print out of 35,800 copies and its main focus is on publicizing and disseminating Brazilian scientific and technological production. As its site informs, the magazine, "functions as a pole for contact and the continuous recognition of Brazilian researchers and serves as an indispensible reference for science and technology editors attached to Brazilian national communication entities" (REVISTA PESQUISA FAPESP, 2009).

Pesquisa FAPESP works only with journalistic texts in in the categories "informative" (news items, reports, and interviews) and "opinionative" (articles and reviews). There is also space for literary contributions and each issue carries at least one short story. In addition there are info-graphs, illustrations and high quality photographs to accompany the written material and make a harmonious contribution to the overall information.

Superinteressante, produced by the Abril publishing group, defines itself as a young and attractive entity in the Scientific Dissemination segment: "It is innovative in its selection of themes and addresses, in a creative way, the topics that everyone is talking about, anticipating tendencies and giving the reader really first hand information on what is coming" (SUPERINTERESSANTE, 2009). 
Again according to the publication's own site, a poll in 2007 organized by Marplan (a media and market polling and research organization) and the IVC (a circulation verification organization) gathered data on the magazine's reader profile and circulation. 52\% of readers are in the 20 to 39 age group, predominantly male (54\%) and most of them belonging to social classes $A$ and $B$. The number of readers was registered as 2,614,000 with a print out of 405,417 copies per issue. The Brazilian southeast macro-region accounts for $49 \%$ of its circulation, followed by the south with $22 \%$.

\section{SCIENTIFIC DISSEMINATION AND THE SUBJECTIVITY OF THE LANGUAGE}

The French school of discourse analysis, particularly the works of Maingueneau and Charaudeau on ethos, scenography and communication contract are the theoretical references that offer elements for identifying the discursive characteristics of the Scientific Dissemination magazines that make up the corpus of this study, namely all the issues for 2009 and 2010 of the Scientific American Brasil, Revista Pesquisa FAPESP and Superinteressante magazines. The research is qualitative but with a descriptive approach developed on the basis of a review of the respective literature and observation of the selected corpus.

Insofar as it defends the idea that discourse is the locus of power articulation, the French school of Discourse Analysis has provided us with the necessary theoretical support for observing the magazines' behavior in the way they handle the selected themes and the way in which each magazine relates to the audience it wishes to reach out to.

There are various linguistic elements in the informative materials that enable us to analyze the journalistic discourse in the light of its being imbued with intentionality whereby "the subject comes to occupy a privileged position and the language comes to be considered the locus of the constitution of the subjectivity" (BRANDÃO, 2004, p. 45). In the sphere of Scientific Dissemination, a study of the selection of materials that make up each publication revealed precisely that relation between text and context, in other words, between the contents displayed and the way in which they are displayed, and the determinant production context. Various factors external to the text contribute towards its being selected for publication and to determining the way in which the subject matter is treated, thereby marking the existence of an intimate relation between the discourse and the conditions associated 
to its production, considering that, "the method of language analysis instituted by discourse analysis [...] focuses precisely on how the relation of the language to the conditions (or situation) in which it is produced, that is, its socio-historical-cultural context" (ORLANDI, 1989, p. 12).

Thus the departure point is the linguistic text itself, observing, for example, the different forms used by the author to introduce the speech of the other into his text. In that perspective, Marcuschi (1991) conducted a study of the verbs used to introduce an opinion that journalists usually use to introduce the speech of the other, some of them being referential but others more heavily tinged with judgment. According to that author (1991, p. 72), "the opinion is introduced by a verb which anticipates the general nature of the opinion being narrated", that is, such verbs act selectively on the contents that follow, impressing on them an interpretive intentionality with ideological characteristics and revealing the narrator's own perception of the contents, of the fact observed or the discourse being reported.

In the textual analysis, based on the linguistic markers, in a similar way to the verbs mentioned above, the argumentative operators, grammatical elements like prepositions and conjunctions also participate in the sense of leading to an identification of the discursive formation that the texts are linked to. The function of such elements in the text is to orientate towards a certain reading of it as, for example, by valuing one piece of information to the detriment of another that can be achieved using the adversative conjunction "but" which, when inserted into a given context, bears with it not only the idea of countering, but also of the valuing by the narrator of the preposition or element that it is most directly linked to.

Thus such operators act as an indispensible tool for detecting the "argumentativity" present in the journalistic discourse, especially because the authors of that discourse work with techniques that lend them an air of being neutral and impartial; techniques like those of the socalled "declaratory journalism" where the journalist "speaks out" based on his or her sources or backed by data that are apparently irrefutable.

That means there are several ways to "say" something and consequently various ways to interpret whatever has been said. Every speaker or writer has intentionality which may be explicit to a greater or lesser degree in the lexical choices, the order of phrases, the composition of the para-text and the use of the argumentative operators. According to Koch (1984, p. 24) "every act of interpretation present in everyday language is based on the supposition that whoever is speaking has 
certain intentions associated to the act of communicating. In that sense, understanding an utterance means apprehending those intentions.

The Discourse Analysis approach, especially in the case of Scientific Dissemination discourse that is the object of his study, takes into consideration the multiplicity the discourse's voices as proposed by Bakhtin (1981) which, in this case, is no longer an abstraction because the discourse in question is unified by its means of transmission, albeit different subjects contribute to it: some with orientations in common but others that may eventually conflict with one another. Picking up on Michel Foucault's thinking on power relations in the sphere of language, Brandão (2004, p. 31) states that, "[...] discourse is the space in which knowledge and power articulate, because whoever speaks, speaks from a position are place, based on an institutionally recognized right to do so. That discourse, held to be true, and bearer of (institutional) knowledge, is the generator of power".

Again, in the words of Leibruder (2002, p. 230), "Scientific Dissemination is an eminently heterogeneous practice insofar as it incorporates to its discursive thread not only elements taken from what serves as its main source - scientific discourse - but also, and just as much, elements taken from what it intends to become, journalistic discourse". The authority of the scientist's voice is always present, whether it be in his or her own direct narration or description (when the scientist is the author of the Scientific Dissemination text), or whether it is in the voice of the journalist or the voices of their sources cited in the text. Of the three publications we analyzed, the Scientific American Brasil came closest to using scientific language, the Pesquisa FAPESP magazine to reflective journalistic language and Superinteressante came closer to more factual and immediatist kind of journalism.

Thus a kind of game of images game is established among the actors involved in this communication process: the image that the author has of his reader, the image that the author believes that he constitutes before the reader, the image the reader has of his or her own self and the image of the publication he or she has chosen to read. In the view of Pêcheux' (2010), there is a series of imaginary formations in the discursive processes that designate the places that each one of the interlocutors attributes to himself and to each one of the others and there are also the images each one has of his own place and of that of the other. Reflecting on that discursive functioning, Amossy (2005, p. 142) made the following affirmation: 


\begin{abstract}
The construction of a discursive image of himself is capable of investing the orator with authority, that is, it can influence opinions and model attitudes. That view corroborates the perspectives of pragmatics which considers that the speech act is endowed with power and has an effect on the other in any verbal exchange - in other words, the discourse makes it possible to (inter) act. In all the approaches that place high value on the efficacy of the speech act, the ethos is not only a posture that demonstrates belonging to a dominant group, it is a self-image constructed in the discourse that influences opinions and attitudes.
\end{abstract}

In the case of the analyzed magazines, those images determine the position adopted by the publication in regard to the narrated facts and by the scientific knowledge disseminator, at different moments.

\title{
3 ETHOS AND THE SCIENCE DISSEMINATOR
}

Discourse analysis practice presupposes that enunciative manifestations should be considered as the results of interactions between the interlocutors. Orlandi (2001, p. 117) reminds us that "in the construction are the marks that I place to represent myself to my interlocutor", however, "the anticipation of what the other is going to think is itself constitutive of the discourse at the level of imaginary formations".

Therefore, the analysis should not be limited to the linguistic manifestations or the text alone, taken here as being the first empirical element in which to observe, as we intend to do in this paper, the options for construction of the scenes of the enunciation and the positions of the enunciator and the enunciator's relations with the interlocutor.

In its aspect as discourse, language does not constitute a universe of signs that merely serve as an instrument for communication or to support thought; language as discourse is interaction, it is a mode of social production; it is not neutral, innocent or even natural and that is why it is the ideal place for the manifestation of an ideology (BRANDÃO, 2004, p. 11).

Furthermore, the relation that is established between the sphere of production and that of reception is marked by intentionality, that is to say, there exists an intention to communicate in a certain way and to produce certain effects, taking into account the publication's profile and that of the reader that it has in mind; but those desired effects of meaning cannot be guaranteed to materialize because

[...] every journalistic title or article, every description uttered by a TV or radio news announcer, every explanation offered by a specialized journalist will be loaded with possible effects but only 
a part of them will correspond to their concrete intentions and another part, not necessarily the same, will be reconstructed by the receiver (CHARAUDEAU, 2003, p. 26).

In the specific context of Scientific Dissemination, Leibruder (2002) underscores the fact that the lexical selection and the narrative mode used, the insertion of elements enhancing values on a greater or lesser scale, depend on the context of enunciation in which the contents are inserted; not merely on "the medium which will carry the article, but essentially on the interlocutor it is being directed at" (LEIBRUDER, 2002, p. 236).

The insertion of the author in the text is an inescapable fact. Considering the impossibility of producing a truly neutral text, entirely free of any of its authors positions, the marks of subjectivity will be found to a greater or lesser extent depending on the nature of the work's objectives. In the context of Scientific Dissemination where the text should be considered as a textual production in itself and not as a translation, it is understood that such marks will take different forms depending on the characteristics of each publication and of each individual Science Disseminator.

Thus the enunciator is perceivable in the text not by means of the elements usually attributed to identifying the author, like using the first person singular or using evaluative terms, but instead by the tone used to demonstrate the facts or narrate the ideas, many of which may be innovative in regard to the knowledge areas they refer to. The presence then is perceived by the way things are said, the way the author positions himself or herself in the act of enunciation. In that sense, what we are addressing here is the notion of ethos developed by Maingueneau (2008), basing himself on the theories of Oswald Ducrot:

\footnotetext{
It is not a question of flattering remarks that the speaker may make about his person in the contents of the discourse, quie the conraryy, such remarks run the risk of shocking his audience, but much more of the appearance he gives to the cadence, the intonation, heated or severe, the choice of words, of arguments... In my own terminology I would say the ethos is associated to L, the enunciator as such; and is so, insofar as he is the source of the utterance that he sees as arrayed with certain elements that make it acceptable or refutable. (MAINGUENEAU, 2008, p. 59).
}

In the context of Scientific Dissemination, the relation that is established between the journalist or scientist doing the dissemination and, by means of the communication medium, the reading audience reveals a particular ethos that takes into the specificities of the contents 
being published and the objectives involved in this communicative process. It has the characteristics of a field that lies somewhere between journalistic discourse and scientific discourse, sometimes closer to one sometimes to the other. Thus whoever wishes to disseminate information about scientific and technological progress,, sometimes mistakenly taken to be mere translation, needs to be aware that his or her task goes beyond the limits of pure information.

Maingueneau (2008) explains that the enunciator's ethos reveals itself to the reader through a set of different elements : a) the pre-discursive ethos, which is what is expected of the enunciator beforehand in view of the style of the publication, its reading audience and its commercial objectives; $b$ ) the discursive ethos, involving the tone the enunciator adopts in elaborating the text (the shown ethos) as well as "fragments of text in which the enunciator evokes his own enunciation (spoken ethos), directly [...] or indirectly, using metaphors or allusions or other speech scenarios" (MAINGUENEAU, 2008, p. 71).

Being the kind of text that requires the presence of persuasive appeals to ensure reader participation, the Scientific Dissemination text makes use of varied enunciative composition strategies, to use Maingueneau's (2008, p. 70) terminology, of which the ethos is a constituent part: "By means of the ethos the recipient is in fact invited to a place inscribed in the scene of enunciation implied by the text. That "scene of enunciation" is in turn made up of three scenes which hat author designated as "comprehensive scene", "generic scene" and "scenography". In the case of the present study, the comprehensive scene is the one that characterizes the texts as belonging to the sphere of Scientific Dissemination, given their evident objective; the generic scene, as the name suggests, is what connects the text to the environment of Scientific Dissemination in a specialized publication (it could be in another type of publication or media entity which would characterize a different genre of Scientific Dissemination); and the scenography depends on each enunciation, that is, in each one, different composition and presentation resources are selected and made use of and, consequently, the insertion of the science disseminator's ethos is also different in each one.

\section{THE MULTIPLE DISCOURSES OF SCIENTIFIC DISSEMINATION}

We commence by adopting the presupposition that there is not just one single Scientific Dissemination discourse and accordingly, 
the publications are responsible for constructing different discourses, according to the nature of the publications and of their target audiences and in view of the fact that the enunciative manifestations stem from the interactions among the interlocutors ideologically marked by the language used.

In that regard, Charaudeau (2003) presents the media as if it were a machine producing signs originating from that part of human activity dedicated to constructing social meaning (semiotic logic) which is related to the economic context because every informative body performs as if it were a company whose purpose is to manufacture a product defined by the place it occupies in the consumer goods exchange market (economic logic). Thus, in the discursive perspective, the enunciation should not be addressed in isolation from its enunciative context which last involves aspects ranging from the conditions in which it was produced to the possible conditions of its reception and obviously including the contents that are to be passed on and the impact which the scientific and/or technological knowledge may have on society.

In the Superinteressante magazine in particular, there is an important movement that takes place between the journalist and the scientist - while on the one hand the journalist finds the validation and reinforcement for his own utterance in the speech of the scientist, on the other, he, the journalist assumes the role of guarantor of the veracity of the facts, reassuring the reader that he can safely incorporate himself to the text as regards the information presented in it, or as Maingueneau (2008, p. 53) puts it: "the legitimization of the text involves not only the articulation of propositions, it is also inhabited by evidence of a corporality that is existent in the very movement of the reading".

The lack of sufficient mastery of the technical terms or even of elements primordial to any comprehension of the scientific facts may offer an explanation for the position taken by the Superinteressante magazine which shows itself to be a disseminator of science with an ethos of partnership, of friendship and connivance with the reader. In this publication the disseminator of science and technology is a journalist who sits beside the reader with the status of someone the reader can trust, someone who knows what he is talking about and accordingly speaks authoritatively even though he must have constant recourse to citing the speech of the original researcher to underscore whatever is being exhibited.

In regard to the sources, there is no concern with presenting concrete data regarding the overall process of constructing and 
elaborating the research with all its mistakes, methodology and procedures. In practice what is of interest, in the mistaken view of some journalists, are the results and their practical applications alone, to the detriment of any understanding of the context of scientific and technological production. That is a highly pragmatic vision which tends to boost the process of mythologizing science. The researcher is referred to as someone with entire mastery of the respective knowledge and that serves to ratify or reinforce the ideas being exhibited by the journalist.

Superinteressante also tries to construct a suitable scenography for each content matter and a validation strictly for that single context, making use of elements borrowed from social stereotypes that are capable of persuading the recipient to read the material with close attention and become interested in the contents being displayed. That is yet another resource that the publication uses intensely in its bid to draw as close as possible to the reader: in this case, the language of scientific dissemination is imbued with a sense of fun.

The numbers of subscribers and the circulation figures displayed on the Abril group's site are sufficient to give an idea of their the Superinteressante magazine's market profile. It now sells science to an audience that it has built up over the years, albeit information on science that is far from the Scientific Dissemination that the researchers themselves would wish and which might be capable eventually of really inserting scientific progress into the fabric of society at large, and really making the citizen feel himself to be part of the process. The use of slang and catch phrases in a bid to attract young people that are its target audience also contributes towards the construction of a singular variety of Scientific Discourse on the part of this magazine. On the one hand it is the fruit of a commercial vision of how to maintain contact with audience in question but on the other it can lead to superficiality in the dissemination of the scientific data as if young people were incapable of understanding anything with a meaning that was a little more complex and closer to the reality of scientific facts themselves.

Different in every way from Superinteressante, the Scientific American Brasil is a disseminator of science with a very distinct ethos. In it, the role of disseminator is often taken on by the researcher and the self-distancing from the facts being narrated as well as the characteristics of the magazine's audience mark a more elitist position and a more indepth approach to the knowledge being disseminated. The analysis of the Scientific American Brasil's language revealed that the way scientific research results are presented in the magazine is far from 
being designed to place Brazilian scientific knowledge on the country's discussion agenda. It is a Scientific Dissemination magazine that targets a very specific audience, well-versed in scientific and technological themes and interested in innovations; academic researchers or readers that are, at the very least, well qualified to read complex texts. If on the one hand it is not exactly a communication restricted to peers, it is also not designed to reach out to the ordinary man in the street with little scientific background or with no participation in scientific culture.

The group of Brazilian scientist that appear on the cover of the Scientific American Brasil represent the success obtained by Brazil's scientific development and a firm belief in its continued growth, especially by means of national and international partnerships and collaborations, in spite of the huge distance separating the investments made in science and technology internationally from those provided for in the Brazilian budget, despite the reiterated promises to double them up to the mount of $2 \%$ of the Brazilian GDP. Nevertheless, the Scientific American Brasil magazine has been important in placing Brazilian science among those with research results that are internationally respected.

Because it is an American magazine the emphasis is naturally placed on the science being developed by the United States, as was clearly demonstrated in a quantitative investigation conducted by Gonçalves (2008). The number of Brazilian materials highlighted in the magazine never goes beyond the $30 \%$ that the magazine proposed at the time of its launching the Brazilian edition in 2002. Much of the material is written by the publishers but a considerable part is written by the researchers themselves. In the latter case, scientific discourse predominates over journalistic discourse, quite the opposite of the situation in the Pesquisa FAPESP magazine which, by adopting reports rather than original papers, ensures that journalistic discourse is predominant and maintains a type of language which, while it may not necessarily be readily accessible to young audiences, is at least accessible to the general adult audience and all the more so to university audiences and researchers.

The task of those that wish to disseminate science consists of ensuring the consistency of the data being presented but to present then in a way that makes them accessible to the reader. What we see in the Pesquisa FAPESP magazine is evidence of constant concern with that aspect at all stages right from the selection of topics for texts to the graphic display of the materials. In this sense, the use of metaphor and examples to explain the technical terms being used is richly exploited.

However much the journalist may wish to be objective in 
producing his reports for the Pesquisa FAPESP magazine, he cannot help adopting a stance when addressing a given theme, revealing his or her ethos as a disseminator of science and his position in relation to the fact being reported and in regard to the target audience. Also, the scenographies constructed in each report mark whatever the Scientific Dissemination text has come across in the construction of the enunciation scenes (using Maingueneau's terminology), a resource that can be used to attract the reader and hold his attention to the text and, indeed, a resource that is exploited by journalistic reporters whatever segment they happen to be working with.

Another function attributed to the Pesquisa FAPESP is to present the results of the investments Brazil has made in science and technology to the public; investments that the FAPESP itself has made in Brazilian researchers. Consequently the magazine's main emphasis is on Brazilian research. The magazine has always taken care to present clear well elaborated texts with rich meaningful illustrations, giving priority to the Brazilian researcher working with important international issues. The critical vision of both the magazine and its journalists is apparent in their choices of the enunciations of the sources that are given space in the publication.

\section{FINAL REMARKS}

The scientific Dissemination publications behave differently in their selection of topics to address, in the positions that they adopt and in their relations with their target audiences. While the Scientific American adopts a posture of scientific soundness by exhibiting the enunciations of many of the sources it consults, Superinteressante opts for the level of "conversation" using resources like the qualities of novelty and extraordinariness that make the readers interested in the contents they are reading. Pesquisa FAPESP in turn works its texts with an emphasis on the the enunciations of the journalist supported by those of the sources consulted. In that sense all three of them in common with all the other means of communication, according to Charaudeau (2003), perform as if they were mere distorting mirrors even though they are responsible for a large part of the simplified and stereotyped representations of the world.

The editorial commitment of each one of the magazines to its readers is at the bottom of their discursive constructions. The Scientific American Brasil seeks for explanations in multiple sources maintaining 
a technical approach and a close alignment with science itself. The Pesqusa FAPESP magazine adopts an approach to the themes from the perspective of the Brazilian context and obtains its explanations largely from Brazilian scientists. It grants considerable autonomy to its specialized journalists in addressing the facts and the published texts are of the journalistic reporting genre. Superinteressante, in turn, has a more distant commitment to science and clears its texts of strictly scientific jargon using, instead, catch phrases, slang and types of comparison appropriate the language of its audience.

What Superinteressante is interested in publishing, as its name suggests, is the more attractive facet of science, that which enters in the daily lives of its readers: science that helps to solve crimes, that finds ways of controlling anxiety; that works to save the oceans. Those are themes that permeate people's lives and in which the progress of science can be readily perceived in a practical way, despite the fact that the process involved to arrive at the results it presents may have been long and arduous.

With its cheery pages full of illustrations, info-graphs and plays on words the Superinteressante magazine practically reproduces an image of its audience - young, daring, interested in anything surprising or unprecedented but at the same time demanding speed and objectivity. That means that the magazine's journalist disseminating science in this publication adopts a posture that reveals his ethos as a guarantor and as a partner of the reader, someone who learned something first to be able to pass it on reliably. That reliability and sureness, however, is actually underwritten by the enunciations of the scientists themselves whose voices lend legitimacy to that of the journalist. That interplay of images - of the enunciator and the co-enunciator - represents the processing of what Maingueneau calls the pre-dicursive ethos: the Superinteressante reader knows beforehand what to expect of the magazine and the magazine in turn presents those elements that correspond to the readers' expectations.

The American publication analyzed in this study has a history of disseminating scientific results and technological innovations responsible for significant changes in the life of modern man, that goes back 150 years, and that in itself imbues it with credibility to such an extent that the knowledge it publishes incorporates that same quality of credibility and stands out from the rest. Nevertheless it must be noted that the Scientific Dissemination discourse of this publication is far outside the reach of the general public. In spite of its evident concern to 
explain, define and organize the data in order to make them susceptible to dissemination in a clear and concise form, it makes abundant use of scientific jargon and impermeable forms of language making it accessible only to the few that hold the power of scientific knowledge as a pre-requisite for learning more. Thus the cycle, whereby those who know much are empowered to learn even more, is perpetuated.

\section{NOTES}

1 The date (2010) refers to the work consulted. Pêcheux's theory of Automatic Analysis of Discourse dates back to 1969.

\section{IREFERENCES}

AMOSSY, Ruth (Org). Imagens de si no discurso. São Paulo: Contexto, 2005. BAKHTIN, Mikhail. Marxismo e Filosofia de Linguagem. Trad. Bras. São Paulo: Hucitec, 1981 (Russian original: 1929).

BRANDÃO, Helena H. Nagamine. Introdução à análise do discurso. Campinas: Unicamp, 2004.

BRASILIANA, A Divulgação Científica no Brasil. Available at http://www. museudavida.fiocruz.br/brasiliana/cgi/cgilua.exe/sys/start.htm?sid=14. Accessed on: Oct. 4, 2009.

CALVO Hernando, Manuel. La divulgación científica y los desafios del nuevos siglo. Available at <http:// www.jornalismocientifico.com.br/jornalismocientifico/ artigos/divulgacao_cientifica/artigol.php> Accessed on: Feb. 28, 2006.

CHARAUDEAU, Patrick. El discurso de la información: la construcción del espejo social. Barcelona: Gedisa editorial, 2003.

FERREIRA, Giovandro Marcus. Contribuiç̧̃̃es da Análise do Discurso ao Estudo de Jornalismo. In FRANÇA, Vera [et al.] (Org.) Livro do XI Compôs 2002: Estudos de comunicação. Porto Alegre; Sulina, 2003.

GONÇALVES, Elizabeth Moraes. Divulgação Científica Brasileira: um diagnóstico da Revista Scientific American Brasil. Contemporânea - revista de Comunicação e Cultura, v. 6, p.1-15, 2008.

KOCH, I. V. Argumentação e Linguagem. São Paulo: Cortez, 1984.

LEIBRUDER, Ana Paula. Discurso de Divulgação Científica. In: BRANDÃO, Helena Nagamine. Gêneros do Discurso na Escola. $3^{a}$ ed. São Paulo: Cortez, 2002.

MACEDO, Mônica Gonçalves. Do texto ao hipertexto: argumentação e legibilidade nos discursos da divulgação científica. Tese de Doutorado. PósCom Umesp, 2002.

MAINGUENEAU, Dominique. Cenas da enunciação. São Paulo: Parábola Editorial, 2008. 
MASSARANI, Luisa; MOREIRA, Ildeu de Castro. Divulgación de la ciencia: perspectivas históricas e dilemas permanentes. In: Quark $n^{\circ} 32$, abril-junho de 2004. Available at: <http://www.imim.es/quark>. Accessed on: Mar. 18, 2005.

MARCUSCHI, Luiz Antonio. A ação dos verbos introdutores de opinião. In INTERCOM - Revista Brasileira de Comunicação, ano XIV, nº 64, São Paulo, Janeiro/Julho, 1991.

ORLANDI, Eni P. Discurso e Texto - formulação e circulação dos sentidos. Campinas: Pontes, 2001.

ORLANDI, Eni Pulcinelli; GUIMARÃES, Eduardo; TARALLO, Fernando. Vozes e Contrastes - Discurso na cidade e no campo. São Paulo: Cortez, 1989.

PÊCHEUX, Michel. Análise automática do discurso (AAD-69). In: GADET, F.; HAK, T.(orgs). Por uma análise automática do discurso: uma introdução à obra de Michel Pêcheux. Campinas: Unicamp, 2010.

REIS, José. O que é divulgação científica [on line]. Available at <URL: http:// www.eca.usp.br/nucleos/njr/divulg.htm> Accessed on: Nov. 18, 2001.

REVISTA PESQUISA FAPESP. Quem somos. Available at: http://www. revistapesquisa.FAPESP. $\mathrm{br} / \mathrm{?art}=3185 \& \mathrm{bd}=2 \& \mathrm{pg}=1$. Consulted on: Oct. 4, 2009.

SCIENTIFIC American Brasil. Available at < http://www2.uol.com.br/sciam/ artigos/>. Accessed on: Apr. 20, 2009.

SUPERINTERESSANTE. Available at http://publicidade.abril.com.br/homes. php?MARCA=44. Accessed on: May 11, 2009.

VERÓN, Eliseo. Fragmentos de um tecido. São Leopoldo: Unisinos, 2004.

Elizabeth Moraes Gonçalves is doctor on Social Communication. She is professor at the Post Graduation Program on Communication at Universidade Metodista de São Paulo. She coordinates the research group "Studies on communication and language" COLING. E-mail: bethmgoncalves@terra.com.br 
SCIENTIFIC DISSEMINATION DISCOURSE

BRAZILIANJOURNALISM RESEARCH-Volume 9-Number z-zоI3|219 